\title{
Challenges and Responses of Agri-Food Activities under COVID-19 Pandemic: The Case of the Spanish Territories Producing Wine and Olive Oil
}

\author{
Juan Carlos Rodríguez-Cohard ${ }^{1, * \mathbb{C}}$, Juan José Juste-Carrión ${ }^{2}$ and Antonio Vázquez-Barquero ${ }^{3}$ \\ 1 Department of Economics, University of Jaén, 23071 Jaén, Spain \\ 2 Department of Applied Economics, University of Valladolid, 47002 Valladolid, Spain; juan.juste@uva.es \\ 3 Faculty of Economics and Management, Universidad Autónoma de Madrid, 28049 Madrid, Spain; \\ vazquez-barquero@uam.es \\ * Correspondence: jccohard@ujaen.es; Tel.: +34-953-212069
}

check for updates

Citation: Rodríguez-Cohard, J.C.; Juste-Carrión, J.J.; Vázquez-Barquero, A. Challenges and Responses of Agri-Food Activities under COVID-19 Pandemic: The Case of the Spanish Territories Producing Wine and Olive Oil. Sustainability 2021, 13, 13610. https://doi.org/10.3390/ su132413610

Academic Editor: Antonio Boggia

Received: 28 October 2021

Accepted: 7 December 2021

Published: 9 December 2021

Publisher's Note: MDPI stays neutral with regard to jurisdictional claims in published maps and institutional affiliations.

Copyright: (c) 2021 by the authors. Licensee MDPI, Basel, Switzerland. This article is an open access article distributed under the terms and conditions of the Creative Commons Attribution (CC BY) license (https:/ / creativecommons.org/licenses/by/ $4.0 /)$.

\begin{abstract}
The COVID-19 pandemic has deeply affected economic activities worldwide. The challenge for territories and companies has been how to cope with mobility restrictions. Even in the case of essential activities such as agri-food industries, the adaptation has been a challenging issue to deal with. The paper aims to show how the wine and olive oil industries in Spain have restructured their activities in order to respond to the confinement and the new normalcy, using new technologies as a strategic tool, but also making the most of new actions to keep their presence in the national and international markets. The research was carried out mostly through qualitative analysis, using the in-depth interview as a main tool to gain strategic information from managers of companies and local policymakers. Results show that when local policy makers and managers cooperate, despite the different perceptions they could have, the outcome is positive for facing competitive shocks and carving out new local initiatives, making firms and the territory itself more resilient.
\end{abstract}

Keywords: COVID-19; olive oil; wine; endogenous development; local initiatives

\section{Introduction}

The irruption and rapid global spread of COVID-19 has led the vast majority of countries to face unprecedented challenges in the fields of health and economy. Spain has been one of the most affected countries in the world from both perspectives [1], with one of the highest mortality rates and with a profound economic impact characterized by a major economic contraction, very high unemployment, and an increasingly worrying situation of public finances.

The COVID-19 crisis has severely hit world food production and trade: international logistics problems and a slump in demand-especially during the confinement-via exports, with a strong impact on prices and incomes; rising rigor in health standards (in products and packaging); nationalist pressures on trade agreements; and the boom in online sales, given the collapse of the hotel, restaurant, and catering channel (HORECA) [2,3].

These consequences have been added to the trends challenging agri-food activities (AFA) during the course of the 21st century [4-6]: (a) global population growth, which will require a 50\% increase in agricultural production by 2050 [7]; (b) climate change and resource scarcity, which call for greater sustainability; (c) the integration of food supply chains in order to minimize costs and risks in terms of control, safety, and traceability in a growing regulatory context; (d) an accelerated digital transformation, ranging from precision irrigation to high-tech greenhouses, GIS, and GPS mapping on farms, with data analysis or DNA labeling; and (e) changes in food demand. Notwithstanding, increased overall consumption is juxtaposed with higher demands for quality and variety by an increasingly informed consumer. 
The pandemic has shown the strategic nature of these activities with regard to food security while at the same time putting a face to the humblest links in the food chain, in their daily, absolutely essential work of production and distribution. Our intention is to show the importance of olive oil and wine activities in Spain from a territorial perspective, demonstrating that local firms adapt their responses in collaboration with public bodies within a territorial institutional framework. The study of olive oil and wine activities is especially interesting because, one the one hand, they tend to generate agglomerative phenomena (clusters) in numerous rural areas, which promote the creation of firms and employment and local development processes involving a symbiosis between product and territory [7-10], and on the other hand, because they are two strategic agri-food branches in which Spain is a world leader, with the consequent repercussions on both the local/regional and national economies, as will be demonstrated in the descriptive analysis.

The academic literature has brought about great efforts to study the effects and consequences of the pandemic on different activities of business worldwide [11-14]. More particularly, some of the papers have highlighted the importance of resilience as a challenging process of responding to the consequences of crisis [15-17]. Furthermore, regarding agri-food activities, researchers have posited the effects of the COVID-19 pandemic on agricultural value chains from different perspectives [18-22], also in the case of the olive oil and wine industries in Spain [23-25]. However, none of these studies adopted a placebased approach [26] which considers economic growth and structural change a territorial process where institutions condition the process of capital accumulation [27-31].

Given the fact that wine and olive oil activities in Spain are of great importance in rural territories as generators of employment and value added, it is worthwhile to ask ourselves, adopting a territorial approach, how the actors involved in the territorial value chains are responding to the challenges of the profound transformations that COVID-19 has brought about. Results will show that cooperation among local actors-who build territorial networks-in innovation processes, as well as product and market diversification, are paramount for making territories more resilient to face current and future challenges.

Therefore, the aim of the paper is, first, to corroborate through fieldwork the consequences of the pandemic in the firms producing wine and olive oil in Spain, and second, to find out the changes implemented in order to face it, the learnings that have been taken in, and the panorama for the future expected by managers and owners.

In order to meet these goals, in Section 2, the paper briefly presents the theoretical background under the territorial approach as well as the description of olive oil and wine activities in Spain. In Section 3, the materials and methods used to gain the strategic information about the firms in their territorial context are reported. Section 4 accounts for the main results of the research. Next, a brief discussion on the theoretical implications of these changes on territorial development is offered. Finally, the paper ends with some final comments for future research.

\section{Theoretical Background}

\subsection{The Territorial Approach}

The territorial approach considers that economic growth and structural change is a territorial phenomenon [31-35]. Institutions condition the relations between firms, encouraging trust between the actors and guaranteeing the formal agreements among firms [36]. In turn, innovations will be hampered to reduce production costs and stimulate the presence of firms in the markets if the institutional system does not stimulate interaction among the actors and collective learning through cooperation and agreements between firms and organizations or if the social and institutional environment does not facilitate the best performance in research and knowledge organizations. Furthermore, hidden external economies in territories thrive when the institutional framework is adequate for the demands of the economic, social, and political actors and when institutions promote cooperation among the actors. 
The place-based approach shows that the territory is no longer simply a place where resources and economic activities are located. In this process, the territory works as an agent for transformation because local firms and other actors interact in order to develop the economy and society. It is in this way that the territorial approach allows one to understand the process of economic growth and structural change.

\subsection{Description of Olive Oil and Wine Activities in Spain}

The European Union is a world leader in food production and exports. Thus, in 2018, the nearly 295,000 companies that make up its AFA employed more than 4.8 million people and generated a turnover of EUR 1.2 trillion, with an added value of $1.9 \%$ of the total for the EU-28. The USD 129 billion obtained from foreign trade represent $18.8 \%$ of the world's food and beverage exports, ahead of the United States and China, and the rest of the main exporting countries [5].

Spain recorded higher values than the EU as a whole for the three component areas of the AFA (Table 1): agriculture, industry, and commerce.

Table 1. Weight of agri-food activities in the total value added of the economy.

\begin{tabular}{|c|c|c|c|c|c|c|c|c|}
\hline & \multicolumn{4}{|c|}{ Spain } & \multicolumn{4}{|c|}{ EU-28 } \\
\hline & Agriculture & $\begin{array}{c}\text { Food, } \\
\text { Beverages, } \\
\text { and Tobacco }\end{array}$ & $\begin{array}{l}\text { Agri-Food } \\
\text { Sector }\end{array}$ & $\begin{array}{c}\text { Expanded } \\
\text { Agri-Food } \\
\text { Sector }\end{array}$ & Agriculture & $\begin{array}{c}\text { Food, } \\
\text { Beverages, } \\
\text { and Tobacco }\end{array}$ & $\begin{array}{c}\text { Agri-Food } \\
\text { Sector }\end{array}$ & $\begin{array}{l}\text { Expanded } \\
\text { Agri-Food } \\
\text { Sector }\end{array}$ \\
\hline 2008 & 2.6 & 2.4 & 5.0 & 7.9 & 1.7 & 2.0 & 3.7 & 6.1 \\
\hline 2009 & 2.4 & 2.4 & 4.8 & 7.9 & 1.6 & 2.1 & 3.6 & 6.2 \\
\hline 2010 & 2.7 & 2.5 & 5.1 & 8.4 & 1.7 & 2.0 & 3.7 & 6.2 \\
\hline 2011 & 2.6 & 2.6 & 5.2 & 8.6 & 1.7 & 2.0 & 3.7 & 6.2 \\
\hline 2012 & 2.6 & 2.6 & 5.2 & 8.8 & 1.7 & 2.0 & 3.7 & 6.3 \\
\hline 2013 & 2.9 & 2.6 & 5.5 & 9.2 & 1.9 & 2.1 & 4.0 & 6.5 \\
\hline 2014 & 2.8 & 2.6 & 5.4 & 9.0 & 1.8 & 2.1 & 3.9 & 6.5 \\
\hline 2015 & 3.0 & 2.5 & 5.5 & 9.2 & 1.8 & 2.1 & 3.9 & 6.4 \\
\hline 2016 & 3.1 & 2.5 & 5.6 & 9.3 & 1.8 & 2.1 & 3.9 & 6.4 \\
\hline 2017 & 3.1 & 2.4 & 5.5 & 9.3 & 1.9 & 2.1 & 3.9 & 6.5 \\
\hline 2018 & 3.1 & 2.3 & 5.4 & 9.0 & 1.8 & 2.0 & 3.8 & 6.4 \\
\hline 2019 & 2.9 & 2.4 & 5.3 & 8.9 & 1.8 & 2.0 & 3.8 & 6.3 \\
\hline 2020 & 3.4 & 2.4 & 5.8 & 9.7 & 1.9 & 1.9 & 3.8 & 6.5 \\
\hline
\end{tabular}

Spain presents an intense specialization in the AFA, with that sector emerging as a powerful engine of economic growth and employment, as it is particularly resilient in periods of crisis. However, its role goes beyond this: As the pandemic has shown, it is an essential sector for supplying the food necessary for life, as well as a valuable instrument for territorial development that promotes the rural environment $[38,39]$.

Moreover, the AFA's mixed location patterns-proximity to raw materials and to the market-translate, in Spain, into a broad territorial projection on a municipal scale, typifying the industry of many small or medium-sized towns, based on modest-sized firms, and with territorial brands gaining importance, especially in meat, fruit, and vegetable products, and wines and olive oils, among others [40,41].

Indeed, as shown in Figure 1, Spain is, with almost one million hectares, the world's leading country in vineyard surface area, accounting for around $13.3 \%$ of the world surface in 2018, followed by France, Italy, and China [42]. It is also one of the main wine producers; with around 44.9 million hectoliters in 2018 ( $15.3 \%$ of the world's production), it ranks third after Italy and France. It is also, together with Italy, the leader in wine exports by volume (accounting for $19.1 \%$ of the world in that year), well ahead of the following countries in the ranking: France, Chile, and Australia. 


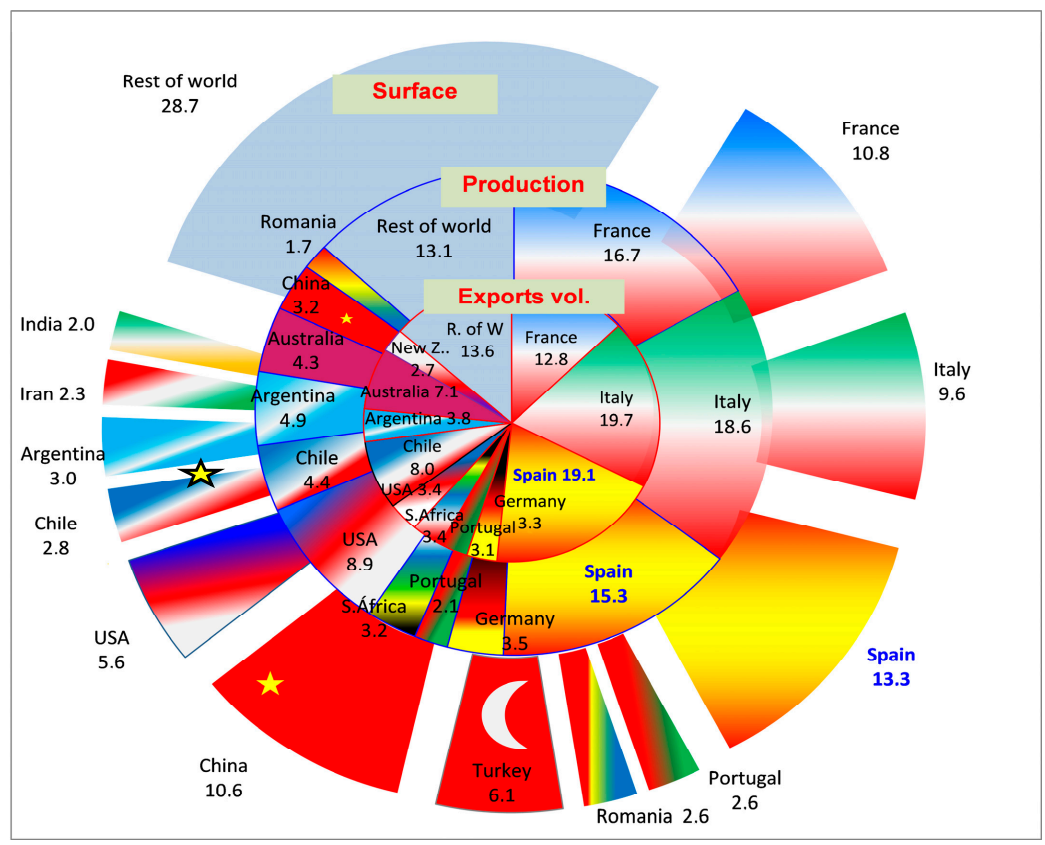

Figure 1. Top wine-producing countries (\% of world total) $(*)$ * Surface and production: 2018; Exports: 2020. Source: own elaboration from the data provided by [43].

Regarding olive oil, Spain undoubtedly leads the world ranking as a producer and exporter (Figure 2). With 1.12 million tons in the 2019-2020 campaign, it produced 35.1\% of the world's volume, tripling the shares of Italy and Tunisia, the second and third largest producers, respectively. Exports in 2019 amounted to USD 3.3 billion-almost half of the world exports in that year-far exceeding the other major exporters: Italy, Portugal, Tunisia, and Greece. Spain is also the world's largest consumer. In the 2019-2020 season, 528,100 tons were consumed, $16.3 \%$ of the world consumption, a figure higher than those of more populous countries such as Italy $(490,000)$ and the United States $(399,500)$.

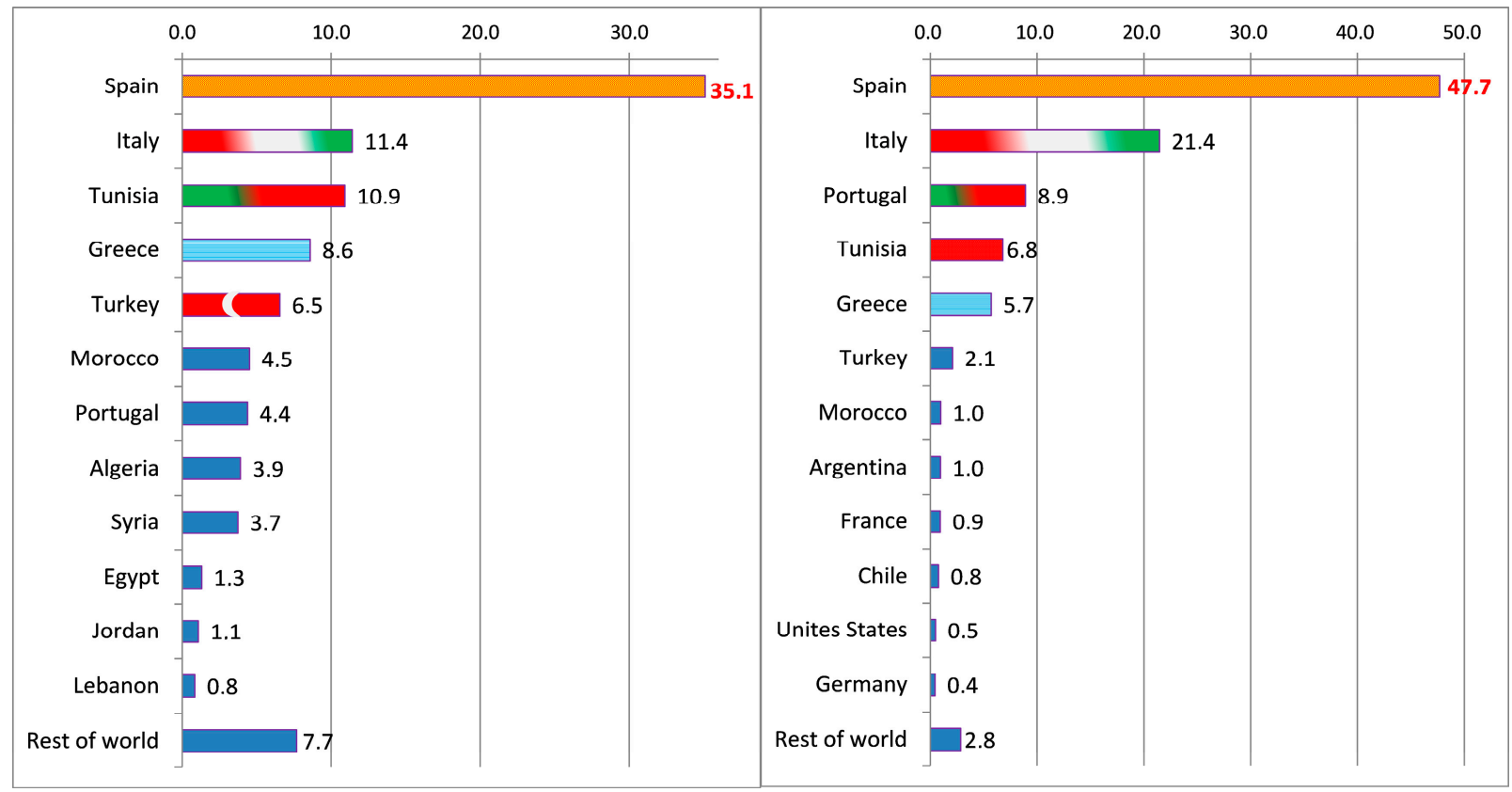

Figure 2. Main olive oil producing and exporting countries (\% of the world production) *. * Production: 2020 ; exports: 2019. Source: own elaboration from data provided by the International Olive Council (IOC) [44]. 
According to INE [45], the wine industry in 2019 had just over 4000 companies, 31,500 jobs, a turnover of EUR 7.8 billion, and an added value of EUR 1.9 billion. In the olive oil branch, 1541 firms employed almost 11,800 workers, with EUR 7.5 billion in sales and almost 600 million in added value. Both branches had a size of just over 7.5 workers per firm, half of the AFA, and a lower unitary labor cost than those from the sector as a whole.

This modest size in Spain is, for wine, the result of a large number of wineries $(33.7 \%$ of those existing in the EU-27), and generates $27.2 \%$ of total EU employment in the subsector, above France and Italy [46]. Furthermore, the analysis of the relative weight of the wine branch within each national AFA places Spain as the second most specialized country after Portugal. For olive oil, Spain's average annual production over the last 10 seasons (1.31 million tons) represents $43.7 \%$ of European production, the most of which is virgin oils, the result of pressing the olives by solely mechanical means. According to Eurostat data [46], taking EU food and beverage production as a reference, Spain is the most specialized country in the EU-27.

The recent evolution of both activities in the pre-COVID-19 scenario is generally positive. Sales and value added rose between 2015 and 2019. This trend-most marked in turnover for wine $(17 \%)$ and in value added for oil $(22.7 \%)$ - has had a visible impact on employment, with an increase over the period of more than $25 \%$ in both cases (Figure 3).

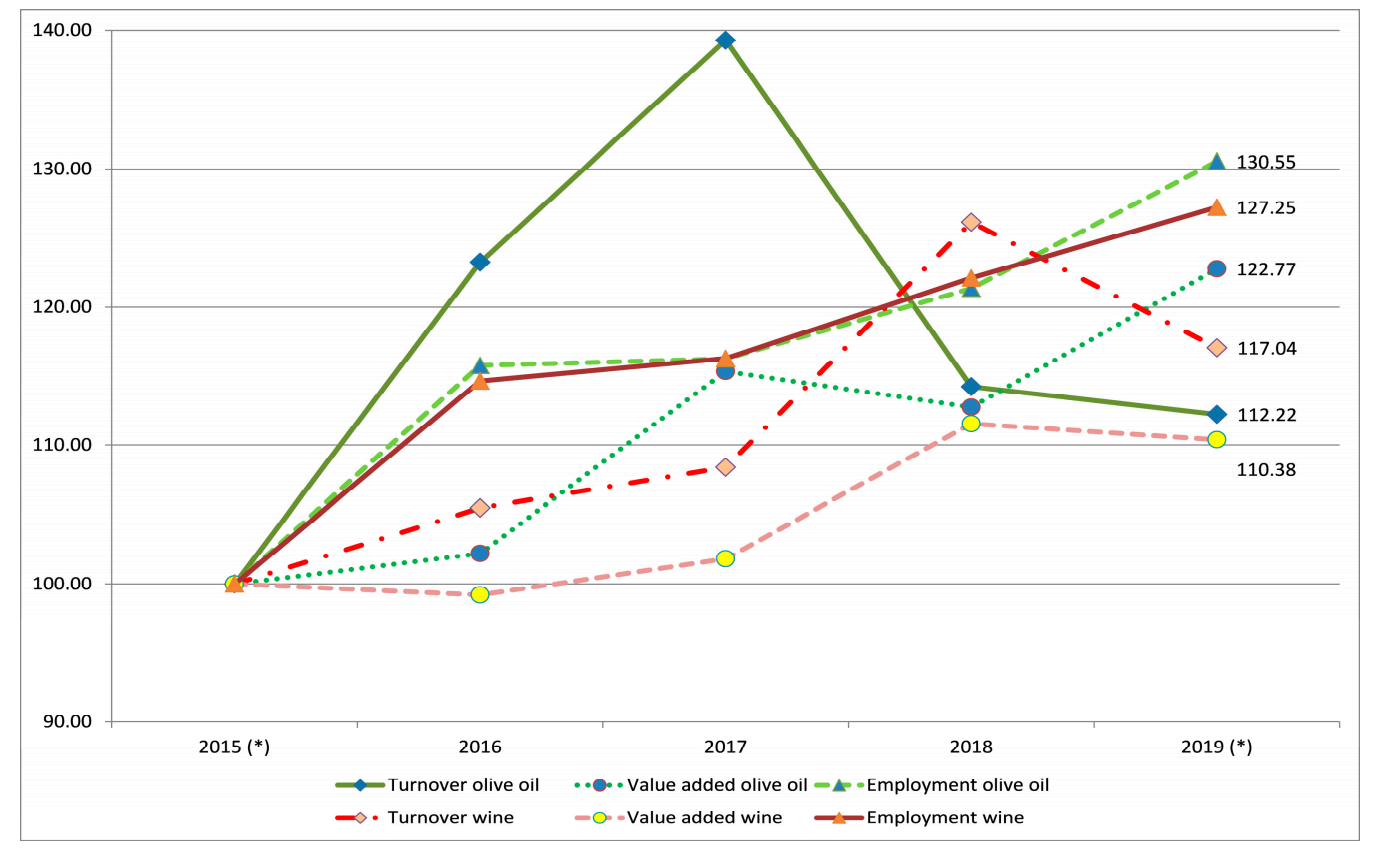

Figure 3. Recent evolution of the Spanish wine and olive oil sectors, 2015-2019. Source: own elaboration. Data from [45]. * Estimated data.

On the demand side, some aspects should be indicated for both branches in Spain. In the case of wine, retail distribution and expenditure in bars and restaurants are crucial; both channels account for $66.8 \%$ of consumption by volume, with table wine predominating at home (34.6\%) due to its low price (EUR 1.41/liter). Per capita consumption is rather modest (23.9 L per year), much lower than in the main producing countries, and particularly high among the over-50s. Olive oil accounts for $60 \%$ of total oil purchases in volume and $81 \%$ in value in hypermarkets, supermarkets, and independent channels (with a prevalence of virgin oils, especially extra virgin) and for $66.1 \%$ in household consumption (compared to $31.6 \%$ for sunflower oil), with refined oil being the most consumed per capita due to its lower price (EUR 3.12/kg) [47]. Foreign consumption is very important for both activities, since Spain is in the trio of the world's largest wine exporters, along with France and Italy. However, unlike them and other major producers, it registers a low average export price 
(EUR 1.26/liter), due to the importance of bulk sales. The number of exporting wineries ranges between 3500 and 4000, with Germany, the United States, the United Kingdom, and France as the main clients, absorbing $42 \%$ of the exported value. In olive oil exports, Spain is the world leader, selling 1.2 million tons the year before the pandemic (61\% extra virgin) for EUR 3.158 billion (63.4\% of world exports in volume and $56 \%$ in value) to 162 countries, with Italy, the United States, and Portugal standing out [46].

From a geographical perspective, the industry is located close to raw materials. In wine, the 950,079 hectares planted with grapes for winemaking are distributed unevenly across all regions according to climatic, soil, and orographic conditions. Castilla-La Mancha stands out, with $47.8 \%$ of the national vineyard area. It is followed by Castilla y León $(8.6 \%)$, Extremadura (8.3\%), the Valencian Community (6.2\%), Catalonia (5.9\%), and La Rioja (5\%), with residual cultivation in Asturias and Cantabria [48], which is reflected in wine production (Figure 4).

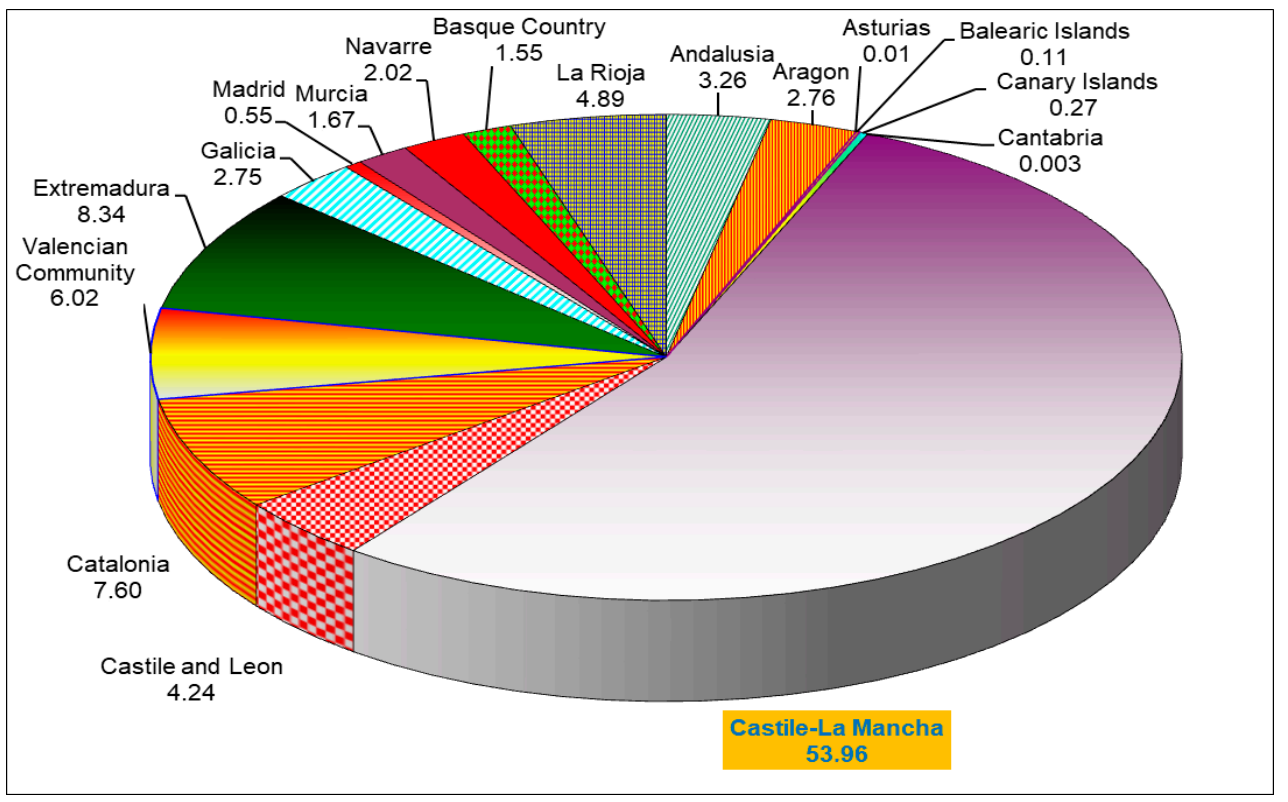

Figure 4. Regional distribution of Spanish wine production, average in 2000-2020. Source: own elaboration from [49].

The territorial distribution of olive oil is less dispersed, given the particular environmental, climatic, and soil requirements of the olive tree. Of the nearly 11.5 million hectares of olive groves in the world, 2.6 million are in Spain: 167,000 are dedicated to producing table olives and bulk, and 2,435,000 hectares are dedicated to olive oil. Andalusia, with more than 1.5 million hectares, gathers $63.2 \%$ of Spain's olive groves for oil production, with Jaén and Córdoba as the most important provinces, representing $24.1 \%$ and $14.8 \%$ of the national surface area, respectively. The second region is Castilla-La Mancha, which contributes $15.3 \%$, followed by Extremadura (8\%). The three regions account for $86.5 \%$ of the total cultivated area [49].

In line with the above, Figure 5 shows, with data from the 2019-2020 campaign, the very strong geographical concentration of production, as well as of the stocks in warehouses at the end of the season, where Andalucía stands out overwhelmingly with $84.8 \%$ of the total stock. In fact, Jaén and Córdoba by themselves account for $52.9 \%$ of national production and $28.1 \%$ of oil mills, whose enormous activity exceeds, on average, that of entire countries.

Table 2 shows data on the 20 largest wine Protected Designations of Origin (PDOs) (of the 95 existing ones) ordered by number of registered wineries, which represent $78.9 \%$ of the area dedicated to PDO vineyards, $75.7 \%$ of the number of winegrowers, $81 \%$ of the 
wineries, and more than three quarters of the total trade of PDO wines, both in volume $(78 \%)$ and in value $(82.6 \%)$.

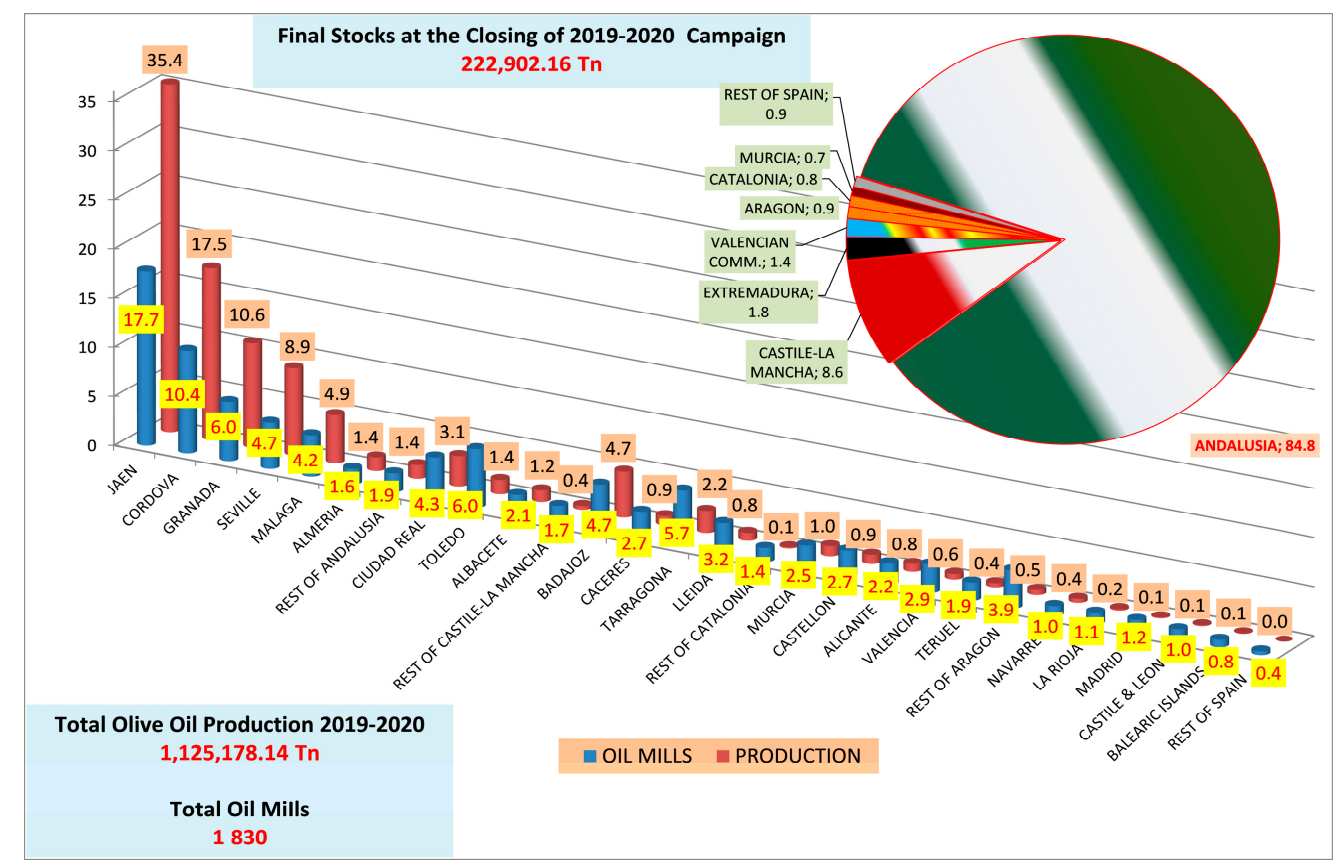

Figure 5. Geographical distribution of Spanish olive oil production, mills, and stocks. Source: own elaboration from the data provided by [50].

Table 2. Main indicators of the 20 largest wine PDOs by number of wineries, 2019.

\begin{tabular}{|c|c|c|c|c|c|c|c|c|c|}
\hline $\begin{array}{c}\text { Designation of } \\
\text { Origin }\end{array}$ & $\begin{array}{l}\text { Surface } \\
\text { Hectares }\end{array}$ & $\begin{array}{c}\text { Number } \\
\text { Winegrowers }\end{array}$ & $\begin{array}{l}\text { Number } \\
\text { Wineries }\end{array}$ & $\begin{array}{c}\text { Volume of } \\
\text { Qualified } \\
\text { Wine }\end{array}$ & $\begin{array}{l}\text { Total Trade } \\
\text { Hectoliters }\end{array}$ & $\begin{array}{c}\text { Exports in } \\
\text { Volume (\%) }\end{array}$ & $\begin{array}{c}\text { Total Trade } \\
\text { EUR }\end{array}$ & $\begin{array}{l}\text { Exports in } \\
\text { Value (\%) }\end{array}$ & $\begin{array}{l}\text { Av. Price } \\
\text { EUR/Liter }\end{array}$ \\
\hline Rioja & 66,239 & 14,882 & 773 & $3,434,068$ & $2,597,136$ & 36.4 & $988,153,761$ & 46.5 & 3.80 \\
\hline Cava & 37,955 & 6582 & 357 & $2,154,267$ & $1,834,248$ & 66.8 & $733,100,903$ & 49.9 & 4.00 \\
\hline Ribera del Duero & 23,314 & 8060 & 316 & 334,901 & 625,532 & 11.9 & $287,919,443$ & 28.0 & 4.60 \\
\hline La Mancha & 156,840 & 14,843 & 246 & 375,272 & 426,495 & 48.9 & $114,855,170$ & 38.3 & 2.69 \\
\hline Cataluña & 41,427 & 6534 & 205 & 361,061 & 428,634 & 42.7 & $120,449,539$ & 41.3 & 2.81 \\
\hline Penedés & 16,500 & 2050 & 180 & 142,627 & 136,006 & 27.7 & $92,946,265$ & 32.1 & 6.83 \\
\hline Rías Baixas & 4051 & 5177 & 178 & 267,572 & 267,568 & 29.2 & $172,677,709$ & 25.4 & 6.45 \\
\hline Ribeiro & 1369 & 1658 & 110 & 85,460 & 91,502 & 9.1 & $77,252,394$ & 15.8 & 8.44 \\
\hline Priorat & 2041 & 531 & 109 & 11,011 & 29,776 & 52.6 & $27,479,200$ & 50.8 & 9.23 \\
\hline Utiel-Requena & 33,886 & 4977 & 107 & 486,324 & 231,476 & 66.1 & $70,417,462$ & 66.8 & 3.04 \\
\hline Valencia & 13,069 & 6150 & 103 & 468,415 & 424,177 & 62.6 & $109,879,654$ & 56.7 & 2.59 \\
\hline Navarra & 10,273 & 1859 & 97 & 483,545 & 333,816 & 30.4 & $69,240,342$ & 36.3 & 2.07 \\
\hline Ribeira sacra & 1236 & 2376 & 94 & 24,643 & 37,800 & 4.0 & $26,682,509$ & 9.7 & 7.06 \\
\hline Bierzo & 2450 & 1309 & 78 & 34,610 & 83,240 & 20.3 & $34,959,736$ & 20.3 & 4.20 \\
\hline Jerez-Xérès-Sherry & 7185 & 1591 & 73 & 506,720 & 234,289 & 78.3 & $70,286,700$ & 78.3 & 3.00 \\
\hline Gran Canaria & 219 & 311 & 71 & 1937 & 2730 & 4.5 & $2,652,699$ & 3.3 & 9.72 \\
\hline Rueda & 18,051 & 1579 & 69 & 766,394 & 767,712 & 10.7 & $214,959,360$ & 10.7 & 2.80 \\
\hline Toro & 5715 & 987 & 65 & 118,127 & 103,854 & 38.0 & $48,466,062$ & 38.0 & 4.67 \\
\hline Terra Alta & 6032 & 1244 & 59 & 77,107 & 44,383 & 15.7 & $12,738,533$ & 26.6 & 2.87 \\
\hline Montsant & 1810 & 602 & 57 & 48,365 & 42,191 & 30.7 & $15,426,856$ & 26.4 & 3.66 \\
\hline $\begin{array}{l}\text { TOP } 20 \text { by n. } \\
\text { Wineries }\end{array}$ & 449,662 & 83,302 & 3347 & $10,182,426$ & $8,742,565$ & 41.6 & $3,290,544,297$ & 40.9 & 3.76 \\
\hline Total Spain & 569,560 & 110,013 & 4133 & $13,574,234$ & $11,209,086$ & 41.3 & $3,985,946,504$ & 40.1 & 3.56 \\
\hline $\begin{array}{c}\text { Top 20/Total } \\
\text { Spain }(\%)\end{array}$ & 78.95 & 75.72 & 80.98 & 75.01 & 78.00 & & 82.55 & & \\
\hline
\end{tabular}

Source: own elaboration from the data provided by [51].

The territorial panorama associated with these quality designations for wine is completed by 42 Protected Geographical Indications (PGIs), which cover a total surface area of 163,600 hectares (73,100 shared with the PDOs), occupied by 10,935 winegrowers in 2019 and with 709 registered wineries spread over 12 regions. 
Olive oil also has PDOs in 29 territories. They cover an area of 709,500 hectares, spread over 9 regions, employing 128,800 farmers, and accounting for 361 oil mills and 370 bottling and/or marketing firms. Table 3 collects data on the 20 most important in terms of economic value, representing $98.7 \%$ of the turnover, which amounted to EUR 134.9 million in 2019.

Table 3. Main indicators of the 20 largest olive oil PDOs by economic value, 2019.

\begin{tabular}{|c|c|c|c|c|c|c|c|c|c|c|}
\hline & & & & Packaging & Total Tons & Production & Trade & Exports & Av. Price & Economic \\
\hline Designation of Origin & Hectares & Farmers & $\begin{array}{l}\text { Number of } \\
\text { Mills }\end{array}$ & $\begin{array}{l}\text { Trading } \\
\text { Firms }\end{array}$ & Production & $\begin{array}{l}\text { Protect. } \\
\text { POD }\end{array}$ & $\begin{array}{l}\text { Protect. } \\
\text { POD }\end{array}$ & Value $\%$ & EUR/kg & $\begin{array}{c}\text { Value } \\
\text { (th. EUR) }\end{array}$ \\
\hline Baena & 60,000 & 8078 & 17 & 30 & 52,041 & 52,041 & 6938 & 55.2 & 5.50 & 38,160 \\
\hline Priego de Córdoba & 29,628 & 6537 & 13 & 12 & 17,665 & 7066 & 2163 & 33.1 & 6.80 & 14,710 \\
\hline Siurana & 9173 & 4922 & 29 & 29 & 2361 & 2356 & 2356 & 9.8 & 4.38 & 10,320 \\
\hline Sierra de Cazorla & 37,700 & 11,200 & 10 & 20 & 6000 & 5000 & 3500 & 14.3 & 2.60 & 9100 \\
\hline Les Garrigues & 16,107 & 2661 & 17 & 22 & 3286 & 3286 & 1606 & 1.7 & 5.24 & 8420 \\
\hline Estepa & 40,039 & 4148 & 17 & 2 & 12,500 & 3159 & 3129 & 44.1 & 2.60 & 8140 \\
\hline Aceite Bajo Aragón & 21,177 & 3289 & 33 & 5 & 7550 & 2098 & 2098 & 2.5 & 3.50 & 7340 \\
\hline Montes de Toledo & 35,000 & 8500 & 29 & 29 & 23,000 & 15,000 & 1100 & 55.0 & 6.50 & 7150 \\
\hline Sierra Mágina & 60,000 & 11,652 & 23 & 20 & 11,265 & 10,125 & 2140 & 2.7 & 3.10 & 6640 \\
\hline Sierra de Segura & 35,064 & 9817 & 21 & 21 & 4654 & 4654 & 816 & 1.6 & 6.04 & 4930 \\
\hline Aceite de Mallorca & 3872 & 994 & 13 & 22 & 464 & 252 & 293 & 16.1 & 11.85 & 3470 \\
\hline Aceite de la Rioja & 688 & 1290 & 13 & 45 & 425 & 302 & 301 & 6.1 & 10.35 & 3120 \\
\hline Campo de Montiel & 28,986 & 6690 & 11 & 8 & 3657 & 2717 & 875 & 45.4 & 3.00 & 2620 \\
\hline Aceite de Terra Alta & 3320 & 1312 & 7 & 19 & 527 & 502 & 502 & 1.8 & 4.50 & 2260 \\
\hline Antequera & 42,509 & 4934 & 13 & 2 & 2856 & 918 & 780 & 16.7 & 2.36 & 1840 \\
\hline Sierra de Cádiz & 28,000 & 2160 & 4 & 4 & 3266 & 543 & 399 & 0.0 & 3.65 & 1460 \\
\hline Aceite de L'Empordà & 800 & 303 & 5 & 2 & 182 & 182 & 182 & 0.0 & 5.58 & 1010 \\
\hline Baix Ebre-Montsià & 12,111 & 3300 & 11 & 5 & 179 & 179 & 179 & 6.8 & 5.54 & 990 \\
\hline Poniente de Granada & 27,013 & 5700 & 13 & 21 & 28,831 & 1065 & 318 & 0.0 & 2.60 & 830 \\
\hline Aceite de la Alcarria & 28,335 & 543 & 4 & 4 & 1180 & 146 & 127 & 0.9 & 5.18 & 650 \\
\hline $\begin{array}{l}\text { Top } 20 \text { by Econ. } \\
\text { Value Wineries }\end{array}$ & 519,522 & 98,030 & 303 & 322 & 181,888 & 111,590 & 29,801 & 26.9 & 4.47 & 133.160 \\
\hline Total Spain & 709,501 & 128,834 & 361 & 370 & 255,767 & 112,758 & 30,318 & 26.5 & 4.45 & 134,950 \\
\hline Top 20/Total Spain (\%) & 73.22 & 76.09 & 83.93 & 87.03 & 71.11 & 98.96 & 98.30 & 99.9 & - & 98.67 \\
\hline
\end{tabular}

Source: own elaboration from the data provided by [52].

In the case of both wine and olive oil, these territorially embedded designations have an unquestionable socio-economic value for rural areas in a context in constant transformation. Their broad spatial projection generates activity, employment, and territorial image in usually very modest municipalities (especially in the case of wine), together with the impact of complementary activities such as enotourism and oleotourism, with a long way to go in the coming years. The PDOs and PGIs have contributed in many cases to shaping local production systems, as well as to maintaining the population and diversifying production, which are key to any process of integral local development.

This narrative has highlighted the territorial relevance of wine and olive oil activities in rural towns in Spain. In order to accomplish the objectives of the study, and given the fact that agri-food activities are profoundly embedded within territories, we proposed a qualitative method of research that is very useful for interpreting territorial reactions to context changes. In the next section, the paper explains the process, materials, and methods carried out in the research.

\section{Materials and Methods}

The research was designed to analyze the responses of Spanish wine and olive oil territories to dealing with the challenges that the COVID-19 pandemic has imposed on their productive and commercial activities. To this end, the study was carried out in different parts of the regions of Andalucía and Castilla y León, where olive oil and wine are the most prominent agri-food activities. Public bodies and local stakeholders took part as key informants and, for the sake of diversity, companies of various types of capital and sizes, and with different economic dynamics and corporate structures, were interviewed [53]. Available quantitative data on sectoral reports were used to assess the relative weight of wine and olive oil activities in the selected regions [54]. 
A qualitative research design was created to investigate the actions taken by companies and supported by public bodies and entrepreneurial associations. All of them were analyzed using an interpretivist framework [55], which allows the exploration of subjective values that individuals create to form their own reality, interacting with others [56]. Qualitative research is a systematic and subjective approach to highlight and explain daily life experiences and give them meaning [57]. Conceptually, individuals perceive the world differently because of their own experiences and perceptions in different contexts [58].

In-depth semi-structured interviews with the heads of firms of different types, such as co-operatives, limited companies, and public and private associations, permitted us to study how these territories are changing their way of working. Interviewee recruitment was conducted using web pages, mass media advertising, technical magazines in the wine and olive oil fields, and the information accumulated in previous research by the authors [7,59-63], as well as informal and non-codified information spread out in the professional environment of wine in Castilla y León and olive oil in Andalucía. Twenty people were identified (see Table 4 for demographic data) and interviewed face to face for at least $60 \mathrm{~min}$ [64]. Although a research limitation could be the small size of the sample, the decision about when to stop conducting more interviews was made once responses became redundant, i.e., when they seemed have reached the point of saturation [65]. This number was sufficient given the homogeneous nature of the cultural, institutional, and economic environment in which the research was carried out: Castilla y León for wine and Andalucía for olive oil.

Table 4. Demographic data of the respondents.

\begin{tabular}{ccc}
\hline Attribute & Modality & Percentage \\
\hline \multirow{2}{*}{ Gender } & Male & 62.5 \\
\cline { 2 - 3 } & Female & 37.5 \\
\cline { 2 - 3 } & $\geq 50$ & 43.75 \\
\cline { 2 - 3 } & $41-44$ & 37.5 \\
\hline \multirow{2}{*}{ Job position } & $\leq 40$ & 18.75 \\
\cline { 2 - 3 } & Top manager & 68.75 \\
\cline { 2 - 3 } Experience in the activity & Middle manager & 31.25 \\
\cline { 2 - 3 } & $\geq 10$ years & 62.5 \\
\hline \multirow{2}{*}{ Academic background } & 6-9 years & 25 \\
\cline { 2 - 3 } & S5 years & 12.5 \\
\cline { 2 - 3 } & Doctoral studies & 68.75 \\
\hline & Bachelor's & 18.75 \\
\hline
\end{tabular}

Source: own elaboration.

The interviewees were asked to present a strategic situation of their organization under the pandemic situation. They described in detail the most notable innovative initiatives being pursued, including a description of them, the nature of the changes, the goals achieved, the resistance encountered, and the most important lessons learned so far from the process. The information extracted from entrepreneurs, stakeholders, and public leaders permitted us to forecast the potential that the actions implemented offer for the company and the territory in order to increase their capacity to respond to challenges in the future.

The fieldwork was carried out during the last quarter of 2020 and the first quarter of 2021, including visits and direct contact and web platforms such as Meet, Teams, and Skype, as well as telephone conversations to contrast possible misleading data. The notes taken during the interviews, as well as the transcriptions of the conversations, were grouped the- 
matically, guaranteeing the anonymity of the data. The use of content analysis allowed us to analyze and contrast them with theoretical arguments and empirical evidence, as is usually done in qualitative studies [66-68]. Mayring [69] defined this as a text analysis method empirically and methodologically controlled within the context of communication. Following thematic analytical rules and a step-by-step process without rash quantification and the use of a deductive approach allowed us to process the data to identify different categories.

The step-by-step process [70] is a useful method to find themes from the raw data. In our research it involved 6 phases of analysis: transcription of the data from the recorded interviews and revision of the written notes, code generation from the data set in order to identify possible topics, the search for links among them, the identification of themes, final generation of the thematic map (see Figure 6), and the production of the final report of the field work. (An example of the process: (1) raw data: "Some of our employees have been moved from production to the new department of online sales we have opened"; (2) coding for "reorganization," "new technologies," and "new markets"; (3) finding links among possible topics: "qualifications," "new strategies," "shutdown," "public aid" etc.; (4) generating different thematic maps (see the final map in the text); (5) producing the final report, and (6) producing the paper.).

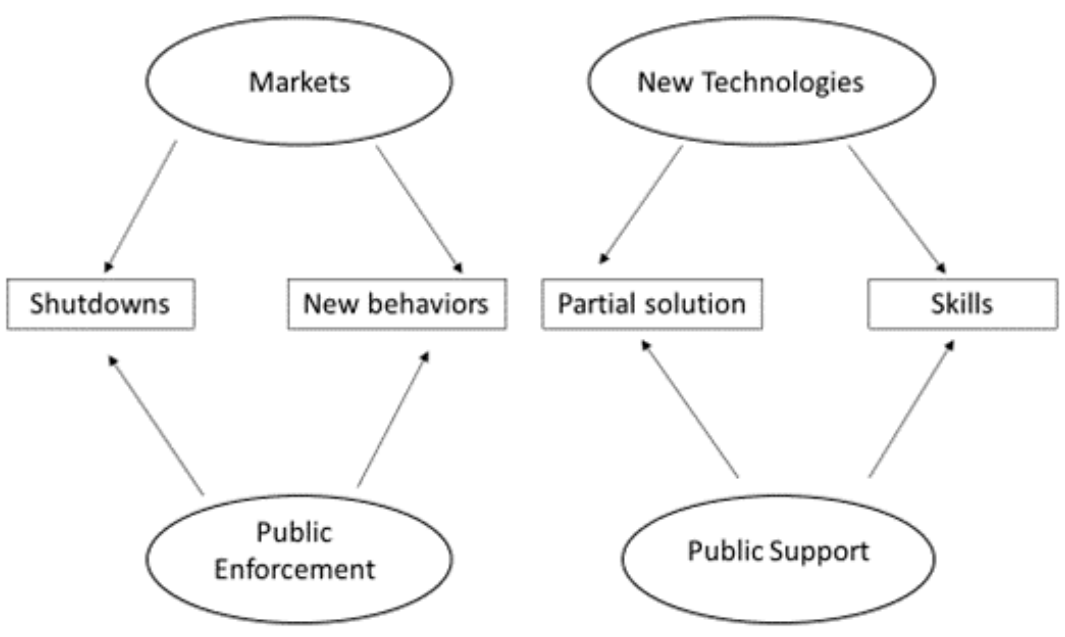

Figure 6. Final thematic map. Source: own elaboration.

The method used to identify territorial responses led by wine and olive oil companies, stakeholders, and public local bodies tested the managerial, technical, and organizational innovations identified and, afterward, explored whether they had provoked a change in rural societies on habits, routines, ways of thinking, ideas, or myths. In short, the research contrasted the innovative responses incorporated in olive oil and wine firms in the rural milieu facing a once-in-a-century challenge.

\section{Results}

The thematic analysis permitted us to identify key content from the data set. The outcome was grouped into four clusters using a territorial approach to build our narrative. The results show that cooperation between actors depends on the shared institutions, but motivations could differ.

\subsection{Spanish Wine and Oil Activities in the Face of the COVID-19 Crisis: The Effects of the Confinement}

During the years before the pandemic, world wine consumption was stable at around 240-245 million hl per year, in a context where the extra-Mediterranean countries increased their demand and the Mediterranean ones reduced it. In line with agri-food activities, the possible impact of the pandemic in 2020 was only $2.9 \%$, although there was a trend of reduction in global consumption after 2019 (See Table 5). 
Table 5. Evolution of wine consumption share in the main consuming countries $\left(^{*}\right)$.

\begin{tabular}{|c|c|c|c|c|c|c|c|c|c|c|c|c|}
\hline Countries & 2001 & 2011 & 2012 & 2013 & 2014 & 2015 & 2016 & 2017 & 2018 & 2019 & 2020 & Cons.pc \\
\hline France & 14.9 & 11.7 & 11.5 & 11.5 & 11.4 & 11.2 & 11.6 & 11.6 & 10.6 & 10.3 & 10.6 & 46.0 \\
\hline Italy & 13.3 & 9.1 & 8.9 & 8.6 & 8.1 & 8.8 & 9.2 & 9.2 & 9.2 & 9.5 & 10.5 & 46.6 \\
\hline Germany & 8.8 & 8.1 & 8.3 & 8.4 & 8.4 & 8.4 & 8.3 & 8.0 & 8.2 & 8.2 & 8.5 & 27.5 \\
\hline Spain & 6.3 & 4.1 & 4.1 & 4.0 & 4.1 & 4.0 & 4.1 & 4.3 & 4.5 & 4.3 & 4.1 & 23.9 \\
\hline Portugal & 2.1 & 2.0 & 2.1 & 1.7 & 1.8 & 2.0 & 1.9 & 2.1 & 2.1 & 1.9 & 2.0 & 51.9 \\
\hline Romania & 2.1 & 1.7 & 1.8 & 1.9 & 1.9 & 1.6 & 1.6 & 1.7 & 1.6 & 1.6 & 1.6 & 23.5 \\
\hline The Netherlands & 1.5 & 1.4 & 1.4 & 1.4 & 1.4 & 1.4 & 1.5 & 1.5 & 1.5 & 1.5 & 1.5 & 24.2 \\
\hline Belgium & 1.1 & 1.2 & 1.2 & 1.2 & 1.1 & 1.2 & 1.1 & 1.1 & 1.1 & 1.1 & 1.1 & 26.9 \\
\hline Austria & 1.0 & 1.0 & 1.1 & 1.2 & 1.2 & 1.0 & 1.0 & 1.0 & 1.0 & 1.0 & 1.0 & 29.9 \\
\hline Sweden & 0.6 & 0.9 & 0.9 & 1.0 & 1.0 & 0.9 & 1.0 & 0.9 & 0.9 & 1.0 & 0.9 & 27.0 \\
\hline Czechia & 0.4 & 0.9 & 0.7 & 0.7 & 0.7 & 0.8 & 0.9 & 0.9 & 0.9 & 0.9 & 0.9 & 23.2 \\
\hline Others EU-27 & 6.7 & 6.9 & 6.7 & 7.6 & 6.8 & 5.6 & 6.7 & 6.0 & 4.7 & 6.8 & 5.3 & - \\
\hline EU-27 & 58.6 & 49.0 & 48.7 & 49.1 & 47.8 & 47.2 & 48.7 & 48.4 & 46.2 & 47.9 & 47.9 & 22.1 \\
\hline United Kingdom & 4.5 & 5.3 & 5.3 & 5.2 & 5.2 & 5.2 & 5.3 & 5.3 & 5.3 & 5.4 & 5.7 & 23.8 \\
\hline Switzerland & 1.4 & 1.2 & 1.1 & 1.2 & 1.2 & 1.2 & 1.1 & 1.1 & 1.1 & 1.1 & 1.1 & 35.7 \\
\hline Russia & 2.7 & 5.2 & 4.6 & 4.3 & 4.6 & 4.4 & 4.1 & 4.2 & 4.1 & 4.2 & 4.4 & 8.6 \\
\hline United States & 9.3 & 12.0 & 12.3 & 12.7 & 12.7 & 12.7 & 12.8 & 12.8 & 13.3 & 13.7 & 14.1 & 12.2 \\
\hline Canada & 1.2 & 1.9 & 2.0 & 2.0 & 1.9 & 2.0 & 2.0 & 2.0 & 2.0 & 2.0 & 1.9 & 13.9 \\
\hline Argentina & 5.3 & 4.0 & 4.1 & 4.3 & 4.1 & 4.2 & 3.8 & 3.6 & 3.4 & 3.7 & 4.0 & 27.6 \\
\hline Brazil & 1.4 & 1.5 & 1.3 & 1.4 & 1.3 & 1.4 & 1.3 & 1.3 & 1.4 & 1.5 & 1.8 & 2.6 \\
\hline China & 4.8 & 6.8 & 7.6 & 7.7 & 7.2 & 7.5 & 7.9 & 7.9 & 7.2 & 6.2 & 5.3 & 1.0 \\
\hline Japan & 1.2 & 1.1 & 1.3 & 1.4 & 1.5 & 1.4 & 1.4 & 1.4 & 1.4 & 1.5 & 1.5 & 3.1 \\
\hline Australia & 1.7 & 2.2 & 2.2 & 2.2 & 2.2 & 2.3 & 2.2 & 2.4 & 2.5 & 2.4 & 2.4 & 27.8 \\
\hline South Africa & 1.7 & 1.5 & 1.5 & 1.5 & 1.7 & 1.8 & 1.8 & 1.8 & 1.8 & 1.6 & 1.3 & 7.4 \\
\hline Rest of the world & 6.1 & 8.2 & 8.0 & 6.7 & 8.6 & 8.8 & 7.5 & 7.6 & 10.6 & 8.8 & 8.5 & - \\
\hline World Total (\%) & 100.0 & 100.0 & 100.0 & 100.0 & 100.0 & 100.0 & 100.0 & 100.0 & 100.0 & 100.0 & 100.0 & - \\
\hline $\begin{array}{l}\text { World (million } \\
\text { hl.) }\end{array}$ & 227.5 & 242.5 & 243.5 & 242.0 & 241.2 & 242.9 & 244.4 & 245.5 & 244.4 & 240.9 & 233.9 & - \\
\hline
\end{tabular}

$(*)$ Cons.Pc $=$ consumption per capita. Source: own elaboration from the data provided by [37].

Likewise, olive oil consumption is growing and the participation of the main consumers, such as Italy and Spain, is decreasing in favor of some extra-European countries, notably the USA (see Table 6). The high and medium-high income consumers demand olive oil despite its highest prices in relation to other vegetable substitutes, such as sunflower or soy oils, thanks to their benefits for health [71].

Table 6. Evolution of olive oil consumption share in the main consuming countries $\left({ }^{*}\right)$.

\begin{tabular}{cccccccccccc}
\hline Countries & $\mathbf{2 0 0 1 -}$ & $\mathbf{2 0 1 1 -}$ & $\mathbf{2 0 1 2 -}$ & $\mathbf{2 0 1 3 -}$ & $\mathbf{2 0 1 4 -}$ & $\mathbf{2 0 1 5}-$ & $\mathbf{2 0 1 6 -}$ & $\mathbf{2 0 1 7 -}$ & $\mathbf{2 0 1 8 -}$ & $\mathbf{2 0 1 9 -}$ & $\mathbf{2 0 2 0 -}$ \\
& $\mathbf{2 0 0 2}$ & $\mathbf{2 0 1 2}$ & $\mathbf{2 0 1 3}$ & $\mathbf{2 0 1 4}$ & $\mathbf{2 0 1 5}$ & $\mathbf{2 0 1 6}$ & $\mathbf{2 0 1 7}$ & $\mathbf{2 0 1 8}$ & $\mathbf{2 0 1 9}$ & $\mathbf{2 0 2 0}$ & $\mathbf{2 0 2 1}$ \\
\hline Spain & 24.2 & 18.6 & 16.3 & 17.1 & 16.9 & 16.6 & 16.2 & 15.7 & 16.2 & 16.3 & 17.0 \\
Italy & 28.2 & 19.8 & 18.4 & 20.8 & 19.6 & 20.1 & 16.1 & 19.1 & 14.8 & 15.2 & 16.0 \\
France & 3.6 & 3.6 & 3.8 & 3.6 & 3.6 & 3.8 & 4.0 & 3.4 & 4.5 & 3.7 & 3.7 \\
Greece & 10.4 & 6.5 & 6.0 & 4.6 & 4.5 & 4.7 & 3.9 & 4.3 & 3.9 & 3.6 & 3.6 \\
Portugal & 2.4 & 2.5 & 2.5 & 2.4 & 2.4 & 2.3 & 2.6 & 2.5 & 1.8 & 2.5 & 2.5 \\
Germany & 1.5 & 2.0 & 2.0 & 2.1 & 2.2 & 2.1 & 2.2 & 2.0 & 2.1 & 1.7 & 1.8 \\
Others EU-27 & 1.8 & 3.3 & 3.4 & 3.6 & 3.7 & 3.9 & 3.9 & 3.5 & 3.8 & 3.3 & 3.8 \\
EU-27 & 72.1 & 56.3 & 52.4 & 54.3 & 52.9 & 53.5 & 48.9 & 50.4 & 47.2 & 46.3 & 48.5 \\
United States & 7.2 & 9.7 & 9.6 & 9.8 & 10.1 & 10.8 & 11.6 & 10.4 & 11.5 & 12.4 & 11.2 \\
Turkey & 2.1 & 4.9 & 5.0 & 3.4 & 4.3 & 3.9 & 5.5 & 5.8 & 5.3 & 5.4 & 5.3 \\
Morocco & 2.3 & 4.0 & 4.3 & 3.9 & 4.1 & 4.0 & 4.4 & 3.9 & 4.9 & 4.3 & 4.4 \\
Brazil & 0.9 & 2.2 & 2.4 & 2.4 & 2.3 & 1.7 & 2.2 & 2.5 & 2.8 & 3.2 & 3.0 \\
Syria & 3.3 & 4.4 & 5.4 & 5.5 & 4.3 & 3.5 & 3.6 & 2.6 & 2.5 & 2.8 & 2.7 \\
Algeria & 1.0 & 1.4 & 2.0 & 1.6 & 2.2 & 2.7 & 2.5 & 2.7 & 3.0 & 3.9 & 2.7 \\
\hline
\end{tabular}


Table 6. Cont.

\begin{tabular}{|c|c|c|c|c|c|c|c|c|c|c|c|}
\hline Countries & $\begin{array}{l}2001- \\
2002\end{array}$ & $\begin{array}{c}2011- \\
2012\end{array}$ & $\begin{array}{l}2012- \\
2013\end{array}$ & $\begin{array}{l}2013- \\
2014\end{array}$ & $\begin{array}{c}2014- \\
2015\end{array}$ & $\begin{array}{c}2015- \\
2016\end{array}$ & $\begin{array}{c}2016- \\
2017\end{array}$ & $\begin{array}{l}2017- \\
2018\end{array}$ & $\begin{array}{l}2018- \\
2019\end{array}$ & $\begin{array}{c}2019- \\
2020\end{array}$ & $\begin{array}{c}2020- \\
2021\end{array}$ \\
\hline Japan & 1.2 & 1.4 & 1.7 & 1.8 & 2.0 & 1.8 & 2.0 & 1.8 & 2.3 & 2.1 & 2.4 \\
\hline China & 0.0 & 1.3 & 1.3 & 1.0 & 1.1 & 1.3 & 1.6 & 1.4 & 1.7 & 1.8 & 2.1 \\
\hline Australia & 1.1 & 1.3 & 1.2 & 1.2 & 1.3 & 1.4 & 1.7 & 1.6 & 1.6 & 1.6 & 1.6 \\
\hline United Kingdom & 1.0 & 1.9 & 2.1 & 2.0 & 2.2 & 2.2 & 2.6 & 2.1 & 2.2 & 0.7 & 1.6 \\
\hline Canada & 0.9 & 1.3 & 1.2 & 1.3 & 1.3 & 1.4 & 1.4 & 1.5 & 1.5 & 1.8 & 1.5 \\
\hline Egypt & 0.1 & 0.2 & 0.4 & 0.6 & 0.7 & 0.6 & 0.8 & 1.3 & 1.5 & 1.2 & 1.3 \\
\hline Tunisia & 1.1 & 1.1 & 1.3 & 1.2 & 1.0 & 1.2 & 0.8 & 1.3 & 1.3 & 1.5 & 1.1 \\
\hline Saudi Arabia & 0.2 & 0.5 & 0.7 & 0.7 & 0.9 & 0.8 & 1.0 & 1.1 & 1.2 & 1.2 & 1.1 \\
\hline Israel & 0.6 & 0.5 & 0.7 & 0.7 & 0.7 & 0.7 & 0.8 & 0.7 & 0.8 & 0.9 & 0.9 \\
\hline Jordan & 0.8 & 0.6 & 0.7 & 0.8 & 0.8 & 1.0 & 0.7 & 0.7 & 0.7 & 0.9 & 0.8 \\
\hline Russia & 0.2 & 0.8 & 0.9 & 1.0 & 0.7 & 0.7 & 0.7 & 0.7 & 0.8 & 0.8 & 0.7 \\
\hline Rest of the world & 4.2 & 6.3 & 6.6 & 6.8 & 7.2 & 7.0 & 7.4 & 7.3 & 7.3 & 7.2 & 7.2 \\
\hline World Total (\%) & 100.0 & 100.0 & 100.0 & 100.0 & 100.0 & 100.0 & 100.0 & 100.0 & 100.0 & 100.0 & 100.0 \\
\hline World (1.000 tn) & 2606.5 & 3085.5 & 2989.0 & 3075.5 & 2916.0 & 2979.5 & 2726.0 & 3039.0 & 3057.0 & 3234.0 & 3185.5 \\
\hline
\end{tabular}

$\left(^{*}\right)$ Cyprus, Poland (2001-2002), and Croatia (2001-2013) included in EU-27. Poland's data for 2001-2002 is from 2003-2004. Source: own elaboration from the data provided by [44].

The measures adopted by governments worldwide in order to contain the spread of SARS-CoV-2 dramatically conditioned the bottom line of firms devoted to delivering products to be offered in the hospitality business. The shutdown of restaurants, bars, and cafés deeply affected the wine and olive oil sectors, although in the latter case only in the highest segments of the market. Furthermore, in the first moments of the crisis the national and international value chains were broken down, which gave rise to a stop in the marketing process. As a consequence, the stocks soared, leading to a plummet in prices. As one interviewee stated,

"Our firm sold a lot in restaurants. Now they are closed. It's frustrating because our products aren't interesting for retailers."

Consumption at home, however, rose thanks to the openness of local essential services, such as supermarkets, bringing about a boost in wines in the medium and low segments of the market and the opportunity for some of the highest quality olive oils to get into kitchens. Consequently, wine firms experienced a twofold situation. On the one hand, firms producing high-quality wines for the hospitality business saw the market close to them, but on the other hand, others making medium- and low-quality wines discovered how unexpectedly sales rose due to the growth of consumption at home. A participant exclaimed that, surprisingly,

"We have hardly been affected by the confinement. In fact, the harvest is sold out."

In this sense, sales of high-quality olive oils also soared, following the path of growing from the last few years, due to the high consideration of the Mediterranean diet in Europe's cuisines.

Touristic activities were eliminated in the portfolio of the companies due to the mobility restrictions.

\subsection{Organizational Changes}

The effects of the pandemic and especially its recurrence have led firms to implement organizational changes, notably in wine companies, where they have had to adopt employment adjustments due to the reduction in sales and the shutdowns of touristic activities.

Job retention programs have incorporated enough flexibility to maintain the activity in some wine companies without increasing the level of unemployment in the region. Others, including most olive oils firms, have not used the ERTEs, as they are called in Spain, because the pandemic has not affected their levels of sales, or, in cases where it has, they 
have adapted their staffs to new activities such as online markets. The following answer is illustrative:

"Some of our employees has been moved from production to the new department of online sales we have opened."

Consequently, special training for staff has been needed to face the challenge of digitization. Electronic commerce has been a solution of emergency for selling high-quality red wines and young white wines, which are made to be consumed in one or two years maximum. In this latter case, production cuts have been one of the actions adopted.

In the case of olive oils, new strategies of digital marketing have been developed. Companies devoted to bulk markets are opening electronic channels to sell their highestquality products in new formats, including unit doses for hospitality business, attractive bottles for the premium extra virgin olive oil, and bag-in-box formats for improving the conditions of the product and offering it at a lower price. The latter has been used for selling low- and medium-quality wines for years, but now it is a solution for high-quality wines and olive oils to be offered online for consumption at home. That is why the most of respondents recognize that:

"People look for new ways for consuming high-quality products for less money."

The most important organizational change has been the adjustment to electronic commerce, which has imposed the need to update web pages and include the possibility of purchasing online. However, in the meantime, the total amount commercialized electronically is less than 3\% [34]. The reasons for such a low level of selling through this channel despite the dramatic situation is that the mechanism of online purchasing needs the construction of a narrative for captivating the client, generally based on the relation between the product, the people involved, and the soil. The narrative is needed in order to connect consumers with the wines and olive oils that are embedded in the local Mediterranean culture, in line with the French concept of terroir, which combines tangible and intangible matters, such as the emotions and experiences that consumers of high-quality wines and olive oils may perceive.

This change has required companies to improve their logistic capacity, signing agreements with delivery firms and commercial chains in national and international markets. Internal processes of management have been modified and videoconferences have been introduced in daily practice.

\subsection{Strategies in the Value Chain}

As a consequence of the pressures in the competitive environment, the prices of grapes were reduced, which compensated in a relative way for the costs of stocking wines for small and medium firms, but in the case of big companies devoted to producing low- and medium-quality wines for big commercial chains, the situation has been very favorable, since the margins have soared.

In the case of small and medium wine firms, the reduction in sales obliged companies to look for cellars in order to stock the unsold annual production, with the logical pressure on prices downstream in the value chain. Likewise, the incorporation of new strategies, such as bottling on demand to maintain the wine in barrels to avoid its degradation, has been rolled out. In fact, only very big companies are able to have a significant strategic volume of bottling wine to provide big European supermarket chains. Some respondents claimed,

"You can't tell a big chain that your stocks are sold out. That business is for bigwineries."

Olive oil companies have also adapted their value chains to the new normalcy. The introduction of delivery for local and regional markets in order to make the most of short value chains has been one of the actions carried out for the newcomers in commercialization from traditional actions in the bulk market. These firms have also boosted the packaging of high-quality olive oils, improving the level of previous sales for national and international 
clients, especially in the market of the United Kingdom, possibly because of the last-minute purchases of big commercial brokers for fear of congestion at borders due to Brexit.

The most innovative companies have incorporated new formats in bottling olive oil to introduce the product in Asia. That is the case of China, Korea, and Japan, where $250 \mathrm{~mL}$ bottles are demanded for medium and high niches of the market. Sales have been growing thanks to the use of online platforms through brokers in destination. Videoconferences and phone calls have substituted traditional face-to-face contact.

Segmentation, diversification, and market expansion are the strategies most reputed wineries are using to face the new context. The very limited stocks for some high-quality wines are preventing these companies from suffering the inconveniencies that the pandemic has introduced in small and medium firms. Others, however, have decided to push an aggressive strategy of low prices for great high-quality wines to be sold in big supermarket chains. Despite the fact that diversification is one of the mantras of olive oil and wine companies, enotourism and oleotourism have been put aside due to the restrictions. However, managers coincided on the perception that these activities are marginal in the final results of the firms. They argued that the costs of touristic activities sometimes are higher than the income, which is why small firms shut down their activity even before the pandemic came. As one participant expressed,

"We had touristic visits for a while, but the costs ... guides, catering service,

cleaning ... were higher than revenues."

Notwithstanding, some companies tackle touristic activities as a medium of promotion of the main products in order to better connect the clients with the symbolic matters that constitute a complete experience to value natural and cultural agri-food products.

\subsection{The Role of Territorial Public Bodies}

Agri-food activities are usually linked to embedded value chains. Because of that, the role of territorial public bodies in supporting them is a key task for local policies. In Spain, innovation, promotion, and supporting industrial activities depend on regional authorities, but we must not always consider them as bottom-up policies due to the size of some regions. That is the case for regions such as Castilla y León and Andalucía, where these policies must be considered top-down ones. However, local bodies such as provincial halls are devoted to promoting and boosting agri-food activities in their territories, mainly because of the importance they have in rural areas, which are under their political competences. Territorial politicians and staff carry out truly bottom-up policies aligned with the local initiatives they want to promote and support.

National top-down policies such as the job retention programs have been very useful for the biggest companies in order to keep the level of employment, but in general they have had a very low impact on total activity due to the fact that production has been maintained in order to attend to the big channels of delivery. Only HORECA has suffered the consequences of the lockdown.

The limitation of production is a traditional goal that agriculture authorities have addressed in order to reduce the oscillations of the market. To this end, aids to reduce harvests in vineyards and stock production in the olive oil sector have been the most used tools to reach the objectives of these policies.

Public aid for improving the processing technology, the intervention of public finances to reduce the financial costs, and support for introducing the products in new markets have been some of the most important top-down regional policies used in the pre-pandemic world. Regional and national agencies such as Extenda and ICEX have permitted companies to improve their international contacts.

Territorial public bodies are especially involved in promoting local products such as wine and olive oil. Given the fact that they are the main agri-food products in these regions, their promotion is a must for the nearer administrations, insofar as they take part in national and international exhibitions in order to spread information about the local 
products, and, more importantly, these actions give an opportunity to small firms to attend international events, which opens the door to new markets for them.

However, there is a significant discrepancy between the perception of public and private managers. Managers of local firms think that local public bodies have relatively low importance in supporting territorial activities, which is more limited for wine than for olive oil, whereas from the perspective of policymakers, their implication for local activities is high in any case.

The differences in perception are even wider when the topic is tourism. For most private managers, tourism is mostly a marginal activity, and some companies are reluctant to consider it profitable. They consider tourism a way to promote the main product, or, in some cases, an institutional activity to catch the attention of regional and national media, but in no case does it have enough potential to be considered a main part of the firm's portfolio. For public bodies, on the other hand, enotourism and oleotourism are among the main activities to be boosted. They have programs to be developed for companies, financial lines to support the firms' investments to implement necessary organizational changes, and so on.

It is important to note that enotourism and oleotourism go beyond agri-food activities, benefiting others such as accommodations, restaurants, transport, etc., which are very important for a country such as Spain, which is very focused on tourism as an engine of growth. These considerations explain the difference between local managers' and territorial policymakers' perceptions about the issue. As one policymaker assessed,

"Our intention supporting tourism within agri-food activities is to create a package for enjoying the territory."

Yet, managers and policymakers agree on the importance of training courses to make the most of digital platforms. Provincial halls have been especially active in organizing training activities for local workers to improve digital competencies. These activities have been very useful for firms to employ swift marketing efforts from the physical to the digital sphere.

On the basis of the territory as a mechanism of resilience, wine and olive oil companies - and the effort made by local public bodies in supporting them-have used different tools in order to deal with the challenges of the international context. The main instrument implemented has been the intensification of digitization. Virtual tasting and territorial e-platforms have allowed visual contact with the client to be maintained, as some policymakers reported:

"Local firms had to maintain the relation with the final market, but the smaller companies couldn't. Local public bodies knew that we had to step forward to create it."

Indeed, the creation of e-marketplaces by local public bodies has been the most worthwhile solution by local companies to fight against the effects of the pandemic. Thanks to this, small firms have been able to commercialize local products in electronic markets without having a webpage. This action is the first step to creating a virtual space for companies to sell local products using the new electronic channels.

From a strategic perspective, territorial public bodies have been key supporters of territorial brands, such as Protected Denominations of Origin and Protected Geographical Indications, which are new territorial institutions improving the level of local resilience. The building of a territorial image is one of the most important contributions of territorial brands as a backbone for promoting local products in international markets.

Notwithstanding the consolidated mechanism of resilience, firms' portfolios have been seriously affected, especially for those who were starting to offer touristic activities. Despite all the managers interviewed considering it a marginal output for the bottom line, this is the area where territorial public bodies have implemented more actions to be promoted. Some innovative firms consider, however, that the best option for their future should be increasing public-private collaboration in the promotion of national consumption, which 
has been reduced in recent times, especially among young people. The bigger ones go beyond: Research and innovation activities should be introduced in territorial collaborative actions in order to find new combinations of products, new ways of marketing, and the better use of territorial potential to increase their resilience capacity and improve their position in the international markets.

In sum, despite the fact that the impact of the pandemic has been high, the mechanisms of resilience rolled out by the different actors within the territory could avoid, in the words of the interviewees, the shutdown of business, though could have absorptions and other processes of firm concentration in the very near future.

\section{Discussion}

Territorial public bodies have helped companies to be resilient in the adjustment process to globalization challenges in the past [72]. Indeed, policies such as promoting diversification, for instance, through tourism; opening new markets, for instance, by easing attending international exhibitions; and enhancing quality, for instance, by creating awards for the best wine or olive oil, have been some of the bottom-up actions provincial town halls have rolled out.

Cooperation is an old concept to boost firms being paradoxically competitive [27]. Thus, bottom-up policies promote institutional collaboration between public bodies and local companies to improve entrepreneurial organization and innovation processes, which are the engines of economic growth [73]. In rural territories, innovation is very often a consequence of cooperation and benchmarking processes, which are the main components of social innovation [63]. Spanish wine and olive oil territories are good examples of these dynamics, since local innovators run the risks of innovating (and harvesting the main benefits if they succeed) but, more importantly for the local society, point out the path to follow.

In this sense, innovation is a territorial process through which social risks are reduced. The mechanism used is to wait and see. Local innovators are leaders-regardless of their size-with the capacity to propose new solutions to new problems. That is why, if they succeed, their decisions - probably questioned in the beginning [62] - spread out the territory, paving the way for other firms and even public bodies to respond to the crisis.

In pandemic times, resilience has been one of the landmarks strategically assumed by companies and public bodies in order to maintain their territorial competitive capacity in national and international markets. Given the fact that locally concentrated agri-food activities are among the most resilient [74] because of the involvement of different and embedded actors, the variety of landowners linked through the territorial value chain, and their production of basic products to attend to human needs, wine and olive oil activities have undergone the consequences of the economic recession better than the majority of businesses.

Yet, their effects on the demand have been very hard, especially for small firms in the wine sector, which were very concentrated on the HORECA channel. In those cases, the territorial social capital is working in favor of the maintenance of the activity, thanks to the bonding linkages local actors have built [75], which allow generational replacement. The latter is especially important for rural territories in Europe, which are under the threat of depopulation [76].

In olive oil territories, the cooperation of local farmers, grouped under the umbrella of the co-operatives, has been an important element for creating their own mechanism of resilience. In fact, for many towns, the olive oil co-operative is the main, if not the only, industry. For this reason, the quality of life depends on the evolution of the activity and the co-operative's capacity to deal with new challenges [63]. However, for other type of business, family tradition, the quest for quality, and the relation between Mediterranean culture and the product is the territorial anchor from where local firms withstand the impact of the pandemic. For wine and olive oil firms, territorial brands, protected by the European Union as PDOs and PGIs, are key elements of competitiveness [10]. 
Despite being both very mature activities, innovation processes are present along the whole value chain, from harvesting to delivering the final product. Thus, the wine and olive oil industries are not absent from the techno-economic paradigm of digitization [77], since the use of electronically connected devices to plants and machinery is usual nowadays in the most innovative producers. In fact, their use ranges from managing the very moment of matureness of fruits, or the accurate process of extraction of the final product, to the use of electronic platforms to sell and promote products, due to the organizational adjustments brought about by the confinement and the new normalcy.

It is important to recognize the role that the confinement has played in fostering digitization in very traditional activities like these. In the new paradigm, production and commercial networks are key for the organization of the value chain in the territory, the absorption of innovations, and the assimilation of the new institutions ruling globalization $[71,78,79]$. However, the assumption of this paradigm for companies entails not only organizational changes but also new capabilities in order to make the most of them. Yet, the process of assuming the new ways of working is slow, but once the new processes are integrated into the daily work of rural societies the situation has no return. As a matter of fact, the pandemic has sparked the incorporation of innovation processes in wine and olive oil activities, especially in commercial and promotional areas, but has also contributed to consolidating the idea of increasing the use of mechanization and new technologies in crops.

New processes of learning are going to be needed in order to understand the best combination of technology, tradition, terroir, and markets to maintain and improve the competitive capacity of the local firms in the new global context. Learning processes are collectively and territorially nurtured [32], mainly because of the importance of the practice [80], and due to tacit and contextual knowledge [81]. Therefore, the new capabilities needed to thrive in the very near future are path-dependent and non-tradable [82], which could constrain the growth in non-innovative territories, such as some of them in rural regions, because the most strategic assets are values, culture, and organizational experience. This is when the role of local public bodies should be strategic to help lead to swift behaviors in the direction of the world market.

\section{Conclusions}

Spanish territories producing wine and olive oil have demonstrated a great resilience during the hardest moments of the pandemic, in line with agri-food activities as a whole. Nevertheless, rural territories face significant challenges for the near future. Although the traditional ones have not been solved, such as the consequences of the lack of competitiveness, deriving from the vicious circle of depopulation, new challenges have also emerged.

In fact, the new normalcy has accelerated the process of digitization in all areas, increasing and diversifying the capabilities needed to manage agri-food business. It is important to note that local public bodies have supported them in keeping an eye on the market in the very beginning of the confinement, but the techno-economic paradigm entails the need for new planning for the long term and a sustainable policy of collaboration between local actors in order to implement successful territorial policies to deal with it.

Agri-food activities are diversified enough in the European soil to be considered strategic in fighting against today's big challenges: climate change, social and territorial inequality, and so on. However, the interrelation of these activities within rural spheres involving bonding dynamics needs to incorporate bottom-up policies to implement more tailored measures. Local development policies could offer an adequate way out of the bottlenecks caused by the lack of skills, maintaining the strategic tacit and contextual knowledge as a source of competitiveness. National [83] and international [84] reports have been released, but the implementation of digitization is far from being started. From now on, local actors in wine and olive oil activities should incorporate territorial governments in 
the challenge of acquiring dynamic capabilities and capacities permitting the management of resilient local agri-food systems, making the most of big data and digital platforms [85].

In order to succeed, it is necessary to reach a strategic agreement between public bodies' and firms' objectives [36]. The design of territorial policies could be condemned to fail if the roadmaps of local agri-food systems differ from the planning and support of local public bodies, since the local actors are competing in a very complex reality, more and more conditioned by the rapid evolution of the institutions leading the new technoeconomic paradigm.

This research has some limitations derived from the small size of the sample and the methodology used for the analysis. The conclusions should be taken with caution out of the area of the research, because they could have been conditioned by the institutional logic of the specific territories where the field work was carried out. It is necessary to conduct more studies in order to assess the results in territories under different economic, geographic, and institutional contexts.

Author Contributions: Conceptualization, J.C.R.-C. and J.J.J.-C.; methodology, J.C.R.-C. and A.V.-B.; formal analysis, J.C.R.-C.; J.C.R.-C. and J.J.J.-C.; resources, J.C.R.-C. and J.J.J.-C.; data curation, J.C.R.-C. and J.J.J.-C.; writing—original draft preparation, J.C.R.-C. and J.J.J.-C.; writing—review and editing, J.C.R.-C., J.J.J.-C. and A.V.-B. All authors have read and agreed to the published version of the manuscript.

Funding: This research received no external funding.

Institutional Review Board Statement: Not applicable.

Informed Consent Statement: Not applicable.

Data Availability Statement: Not applicable.

Conflicts of Interest: The authors declare no conflict of interest.

\section{References}

1. Rodríguez-Cohard, J.C.; Juste-Carrión, J.J.; Vázquez-Barquero, A. Local Development Policies: Evolution and Challenges for Post-COVID-19 Recovering in Spain. Symphonia. Emerg. Issues Manag. 2020, 2, 41-54. [CrossRef]

2. EIT Food. EIT Food Foresight: Impact of Covid-19 on the Food Sector in Southern Europe; Lantern: Madrid, Spain, 2020.

3. OECD-FAO. OECD-FAO Agricultural Outlook 2020-2029; FAO, Rome/OECD Publishing: Paris, France, 2020. [CrossRef]

4. FAO; IFAD; UNICEF; WFP; WHO. The State of Food Security and Nutrition in the World 2020. Transforming Food Systems for Affordable Healthy Diets; FAO: Rome, Italy, 2020. [CrossRef]

5. FoodDrink Europe. Data \& Trends EU Food \& Drink Industry; FoodDrink Europe: Brussels, Belgium, 2020.

6. Rastoin, J.-L. Stratégies D'entreprises Agroalimentaires Dans un Contexte de Globalisation; Séminaire agroalimentaire, Université Laval: Québec, QC, Canada, 2003.

7. Rodríguez-Cohard, J.C.; Parras, M. The olive growing agri-industrial district of Jaén and the international olive oils cluster. Open Geogr. J. 2011, 4, 55-72. [CrossRef]

8. Belis-Bergouignan, M.C. Bordeaux Wines: An Archetypal Terroir Cluster? Open Geogr. J. 2011, 4, 73-90. [CrossRef]

9. Porter, M.E.; Bond, G.C. The California Wine Cluster. Harv. Bus. Sch. Case 1999, 799-124, (Revised February 2013).

10. Sanz-Cañada, J.; Macías Vázquez, A. Quality certification, institutions and innovation in local agro-food systems: Protected designations of origin of olive oil in Spain. J. Rural. Stud. 2005, 21, 475-486. [CrossRef]

11. Donthu, N.; Gustafsson, A. Effects of COVID 19 on business and research. J. Bus. Res. 2020, 117, 284-289. [CrossRef] [PubMed]

12. Kristiana, Y.; Pramono, R.; Brian, R. Adaptation Strategy of Tourism Industry Stakeholders During the COVID-19 Pandemic: A Case Study in Indonesia. J. Asian Financ. Econ. Bus. 2021, 8, 213-223. [CrossRef]

13. Serbulova, N.; Morgunova, T.; Persiyanova, G. Innovations during COVID-19 pandemic: Trends, technologies, prospects. E3S Web Conf. 2020, 210, 02005. [CrossRef]

14. Popa, N.; Pop, A.N.; Marian-Potra, A.C.; Cocean, P.; Hognogi, G.G.; David, N.A. The Impact of the COVID-19 Pandemic on Independent Creative Activities in Two Large Cities in Romania. Int. J. Environ. Res. Public Health 2021, 18, 7674. [CrossRef] [PubMed]

15. Trump, B.D.; Linkov, I. Risk and resilience in the time of the COVID-19 crisis. Environ. Syst. Decis. 2020, 40, 171-173. [CrossRef] [PubMed] 
16. Willy, D.K.; Diallo, Y.; Affognon, H.; Nang'ayo, F.; Waithaka, M.; Wossen, T. COVID-19 Pandemic in Africa: Impacts on Agriculture and Emerging Policy Responses for Adaptation and Resilience Building. TAATaat Policy Compact Working Paper no. wp01/2020. Available online: https:/ / www.farm-d.org/document/covid-19-pandemic-in-africa-impacts-on-agriculture-and-emergingpolicy-responses-for-adaptation-and-resilience-building/ (accessed on 17 November 2021).

17. Zimmerer, K.S.; de Haan, S. Informal food chains and agrobiodiversity need strengthening — not weakening — to address food security amidst the COVID-19 crisis in South America. Food Secur. 2020, 12, 891-894. [CrossRef] [PubMed]

18. Morton, J. On the susceptibility and vulnerability of agricultural value chains to COVID-19. World Dev. 2020, 136, 105132. [CrossRef]

19. Toffolutti, V.; Stuckler, D.; McKee, M. Is the COVID-19 pandemic turning into a European food crisis? Eur. J. Public Health 2020, 30, 626-627. [CrossRef] [PubMed]

20. Galanakis, C.M. The Food Systems in the Era of the Coronavirus (COVID-19) Pandemic Crisis. Foods 2020, 9, 523. [CrossRef] [PubMed]

21. Laborde, D.; Martin, W.; Swinnen, J.; Vos, R. COVID-19 risks to global food security. Science 2020, 369, 6503. [CrossRef] [PubMed]

22. Coluccia, B.; Agnusdei, G.P.; Miglietta, P.P.; De Leo, F. Effects of COVID-19 on the Italian agri-food supply and value chains. Food Control 2021, 123, 107839. [CrossRef] [PubMed]

23. Mili, S.; Bouhaddane, M. Forecasting Global Developments and Challenges in Olive Oil Supply and Demand: A Delphi Survey from Spain. Agriculture 2021, 11, 191. [CrossRef]

24. Rebelo, J.; Compés, R.; Faria, S.; Gonçalves, T.; Pinilla, V.; Simón-Elorz, K. Covid-19 lockdown and wine consumption frequency in Portugal and Spain. Span. J. Agric. Res. 2021, 19, e0105R. [CrossRef]

25. Marco-Lajara, B.; Seva-Larrosa, P.; Ruiz-Fernández, L.; Martínez-Falcó, J. The Effect of COVID-19 on the Spanish Wine Industry. In Impact of Global Issues on International Trade; Özer, A.C., Ed.; IGI Global: Hershey, PA, USA, 2021; pp. 211-232. Available online: http:/ / doi:10.4018/978-1-7998-8314-2.ch012 (accessed on 17 November 2021).

26. Barca, F. An Agenda for a Reformed Cohesion Policy. A Place-Based Approach to Meeting European Union Challenges and Expectations. Independent Report; European Union: Brussels, Belgium, 2009.

27. Beccatini, G. Dal Settore industriale al distretto industriale: Alcune considerazione sull'unita' diindagine dell'economia industriale. Riv. Di Econ. E Politica Ind. 1979, 1, 7-21.

28. Fuà, G. L'industrializzazione nel nord est e nel centro. In Industrializzazione Senza Fratture; Fuà, G., Zacchia, C., Eds.; Mulino Il: Bologna, Italy, 1983; pp. 7-46.

29. Garofoli, G. Endogenous Development and Southern Europe; Avebury: Aldershot, UK, 1992.

30. Stöhr, W.B.; Taylor, D.R. Development from below: The bottom-up and periphery inward development paradigm. In Development from Above or Below? Stöhr, W.B.; Taylor, D.R. Wiley and Sons: Chichester, UK, 1981; pp. 39-72.

31. Vázquez-Barquero, A. Local development and regional state in Spain. Pap. Reg. Sci. Assoc. 1987, 61, 65-78. [CrossRef]

32. Aydalot, P. Milieux Innovateurs en Europe; Economica: Paris, France, 1986.

33. Friedmann, J.; Weaver, C. Territory and Function: The Evolution of Regional Planning; University of California Press: Berkeley, CA, USA, 1979.

34. Sachs, I. Stratégies de L'écodéveloppement; Les Éditions Ouvriéres: Paris, France, 1980.

35. Vázquez-Barquero, A. Endogenous Development: Networking, Innovation, Institutions and Cities; Routledge: London, UK, 2002.

36. Vázquez-Barquero, A.; Rodríguez-Cohard, J.C. Endogenous development and institutions: Challenges for local development initiatives. Environ. Plan. C Gov. Policy 2016, 34, 1135-1153. [CrossRef]

37. FAO. Food Outlook. Biannual Report on Global Food Markets, June 2020; Food and Agriculture Organization of the United Nations: Rome, Italy, 2020. [CrossRef]

38. Maudos, J.; Salamanca, J. Observatorio Sobre el Sector Agroalimentario Español en el Contexto Europeo; Cajamar Caja Rural: Almería, Spain, 2020.

39. Caldentey, P. Nueva Economía Agroalimentaria; Editorial Agrícola Española: Madrid, Spain, 1998.

40. Juste-Carrión, J.J. Producción y exportación de vino en España: El caso de Castilla y León. Estudios de Economía Aplicada 2017, 35, 153-188. [CrossRef]

41. Juste Carrión, J.J. Industria agroalimentaria, desarrollo rural y sistemas productivos locales en Castilla y León. Cuadernos de Estudios Agroalimentarios 2011, 2, 219-252.

42. OIV. Note de Conjoncture Vitivinicole Mondiale 2020; Organisation Internationale de la Vigne et du Vin: Paris, France, 2021.

43. Alimarket. Informe 2021 del sector del Aceite de Oliva en España. Más Envasado Menos Precio; Publicaciones Alimarket: Madrid, Spain, 2021.

44. IOC. World Olive Oil and Table Olive Figures; International Olive Council: Madrid, Spain, 2021. Available online: https://www. internationaloliveoil.org/what-we-do/economic-affairs-promotion-unit/\#figures (accessed on 27 October 2021).

45. INE (Instituto Nacional de Estadística). Estadística Estructural de Empresas: Sector Industrial; Instituto Nacional de Estadística: Madrid, Spain, 2019.

46. Eurostat. Annual Enterprise Statistics for Special Aggregates of Activities (NACE Rev.2); Eurostat: Brussels, Belgium, 2021. Available online: https:/ / ec.europa.eu/eurostat/databrowser/view/SBS_NA_SCA_R2_custom_1437860/default/table?lang=en (accessed on 27 October 2021). 
47. MERCASA. Alimentación en España. Producción, Industria, Distribución y Consumo; Mercasa-Distribución y Consumo: Madrid, Spain, 2021.

48. Ministerio de Agricultura, Pesca y Alimentación. In Anuario de Estadística 2020; MAPA: Madrid, Spain, 2021.

49. Ministerio de Agricultura, Pesca y Alimentación. In Avances de Superficies y Producciones de Cultivos, March 2021; MAPA: Madrid, Spain, 2021.

50. SEVI. Balance de campaña del aceite de oliva a 30 de septiembre de 2020. La Sem. Vitivinícola 2021, 3578, 1795-1798.

51. Ministerio de Agricultura, Pesca y Alimentación. In Datos de las Denominaciones de Origen protegidas de vinos (DOPs) campaña 2018/2019; MAPA: Madrid, Spain, 2020.

52. Ministerio de Agricultura, Pesca y Alimentación. Datos de las Denominaciones de Origen Protegidas (D.O.P.), Indicaciones Geográficas Protegidas (I.G.P.) y Especialidades Tradicionales Garantizadas (E.T.G.) de Productos Agroalimentarios, año 2019; MAPA: Madrid, Spain, 2020.

53. Bortolotti, T.; Boscari, S.; Danese, P. Successful lean implementation: Organizational culture and soft lean practices. Int. J. Prod. Econ. 2015, 160, 182-201. [CrossRef]

54. Lisi, I.E. Translating environmental motivations into performance: The role of environmental performance measurement systems. Manag. Account. Res. 2015, 29, 27-44. [CrossRef]

55. Neuman, W.L. Social Research Methods: Qualitative and Quantitative Approaches; Pearson: Boston, MA, USA, 2011.

56. Carson, D.; Gilmore, A.; Perry, C.; Gronhaug, K. Qualitative Marketing Research; Sage: Thousand Oaks, CA, USA, 2001.

57. Burns, N.; Grove, S.K. The Practice of Nursing Research: Appraisal, Synthesis and Generation of Evidence; Elsevier: St. Louis, MO, USA, 2009.

58. Khan, S.H. Qualitative research method-Phenomenology. Asian Soc. Sci. 2014, 10, 298-310. [CrossRef]

59. Juste Carrión, J.J. The Wine Industry in Spain: The case of Castile and Leon. In Proceedings of the American Association of Wine Economists (AAWE) 10th Annual Conference, Bordeaux, France, 21-25 June 2017.

60. Rodríguez Cohard, J.C.; Sánchez Martínez, J.D.; Garrido Almonacid, A. Strategic responses of the European olive-growing territories to the challenge of globalization. Eur. Plan. Stud. 2020, 28, 2261-2283. [CrossRef]

61. Rodríguez-Cohard, J.C.; Sánchez-Martínez, J.D.; Gallego Simón, V.J. Olive crops and rural development: Capital, knowledge and tradition. Reg. Sci. Policy Pract. 2019, 11, 935-949. [CrossRef]

62. Rodríguez-Cohard, J.C.; Sánchez Martínez, J.D.; Gallego Simón, V.J. The upgrading strategy of olive oil producers in Southern Spain: Origin, development and constraints. Rural. Soc. 2017, 26, 30-47. [CrossRef]

63. Sánchez-Martínez, J.D.; Rodríguez-Cohard, J.C.; Garrido-Almonacid, A.; Gallego Simón, V.J. Social Innovation in Rural Areas? The Case of Andalusian Olive Oil Co-Operatives. Sustainability 2020, 12, 10019. [CrossRef]

64. Hristov, I.; Chirico, A.; Ranalli, F. Corporate strategies oriented towards sustainable governance: Advantages, managerial practices and main challenges. J. Manag. Gov. 2021, 1-23. [CrossRef]

65. Glaser, B.G.; Strauss, A.L. The Discovery of Grounded Theory. Strategies for Qualitative Research; Aldine Transaction: New Brunswick, NJ, USA, 2012.

66. Berelson, B. Content analysis in Communication Research; The Free Press: New York, NY, USA, 1952.

67. Pool, J. Trends in Content Analysis; University of Illinois Press: Urbana-Champaign, IL, USA, 1959.

68. Maxwell, J. Qualitative Research Design. An Interactive Approach; Sage: London, UK, 1996.

69. Mayring, P. Qualitative content analysis. Forum Qual. Soc. Res. 2020, 1, 159-176. Available online: http:/ / nbn-resolving.de/urn: nbn:de:0114-fqs0002204 (accessed on 17 November 2021).

70. Braun, V.; Clarke, V. Using thematic analysis in psychology. Qual. Res. Psychol. 2006, 3, 77-101. [CrossRef]

71. Trichopoulou, A.; Lagiou, P. Healthy traditional Mediterranean diet: An expression of culture, history, and lifestyle. Nutr. Rev. 1997, 55, 383-389. [CrossRef] [PubMed]

72. Vázquez-Barquero, A.; Rodríguez-Cohard, J.C. Local development in a global world: Challenges and opportunities. Reg. Sci. Policy Pract. 2019, 11, 885-897. [CrossRef]

73. Schumpeter, J.A. The Theory of Economic Development Harvard; University Press: Cambridge, MA, USA, 1934.

74. Heijman, W.; Hagelaar, G.; van der Heide, M. Rural Resilience as a New Development Concept. In EU Bioeconomy Economics and Policies: Volume II. Palgrave Advances in Bioeconomy: Economics and Policies; Dries, L., Heijman, W., Jongeneel, R., Purnhagen, K., Wesseler, J., Eds.; Palgrave Macmillan: Cham, Switzerland, 2019. [CrossRef]

75. Putnam, R.D. Bowling Alone: The Collapse and Revival of American Community; Simon and Schuster: New York, NJ, USA, 2000.

76. Delgado Viñas, C. Depopulation processes in European rural areas: A case study of cantabria (Spain). Eur. Countrys. 2019, 11, 341-369. [CrossRef]

77. Pérez, C. Technological revolutions and techno-economic paradigms. Camb. J. Econ. 2010, 34, 185-202. [CrossRef]

78. Cohen, W.N.; Levinthal, D.A. Absorptive capacity: A new perspective on learning and innovation. Adm. Sci. Q. 1990, 35, 128-152. [CrossRef]

79. Pérez, C. Technological Revolutions and Financial Capital: The Dynamics of Bubbles and Golden Ages; Edward Elgar: Cheltenham, $\mathrm{UK}, 2002$.

80. Arrow, K.J. The economic implications of learning by doing. Rev. Econ. Stud. 1962, 29, 155-173. [CrossRef]

81. Dei Ottati, G. Social Concertation and Local Development: The case of Industrial Districts. Eur. Plan. Stud. 2002, 10, 449-466. [CrossRef] 
82. Teece, D.; Pisano, G. The dynamic capabilities of firms: An introduction. Ind. Corp. Chang. 1994, 3, 537-556. [CrossRef]

83. MAPA (Ministerio de Agricultura Pesca y Alimentación). Digitisation Strategy for the Agri-Food and Forestry Sectors and Rural Areas; MAPA: Madrid, Spain, 2019.

84. Elabed, G.; Lampieti, J.; Schroeder, K. What's Cooking: Digital Transformation of the Agri-Food Systems; World Bank Group: Washington, DC, USA, 2021.

85. Mazzucato, M.; Kattel, R. COVID-19 and public-sector capacity. Oxf. Rev. Econ. Policy 2020, 36, S256-S269. [CrossRef] 